\title{
Un estudio de aprendizaje sobre el voluntariado en el sistema de recuperación de emergencia en Rusia: sobre la interacción entre el estado y las organizaciones civiles
}

\section{A learning study on volunteering in the emergency recovery system in Russia: on the interaction between the state and civil organizations}

\author{
Irina Aleksandrovna Zaitseva ${ }^{1 \mathrm{a}}$ \& Aleksander Evgen'evich Krikunov ${ }^{2}$ \\ Bunin Yelets State University, Yelets, Russia ${ }^{12}$ \\ ORCID ID: https://orcid.org/0000-0003-3984-7658 1 \\ (iD) ORCID ID: https://orcid.org/0000-0001-9632-5106²
}

Recibido: 14 de mayo de 2020

Aceptado: 15 de octubre de 2020

\begin{abstract}
Resumen
El propósito del artículo es identificar los motivos, tipos y áreas de voluntariado en el sistema de respuesta de emergencia en la región de Lipetsk, Rusia. Para obtener las características cuantitativas del problema estudiado, se ha utilizado el método de sondeo masivo en el lugar de residencia, trabajo y estudio de los encuestados. El motivo principal de los participantes en las actividades de voluntariado es la razón altruista. El 8,1\% de los voluntarios ha definido su ámbito de actividad como voluntariado en situaciones de emergencia. El 31,9\% está potencialmente preparado para ayudar a las personas en situaciones de emergencia. Esta variación en las cifras podría explicarse por el hecho de que muchos voluntarios no tienen las habilidades necesarias suficientes. Además, la participación en situaciones de emergencia, liquidación, accidentes de tráfico, extinción de incendios, etc., está asociada a un posible riesgo.
\end{abstract}

Palabras clave: situación de emergencia, protección de la población, sociedad civil, voluntariado, actividad social.

\begin{abstract}
The purpose of the article is to identify the motives, types, and areas of volunteering in the system of emergency response in the Lipetsk region, Russia. To obtain quantitative characteristics of the problem studied, we have used the method of mass polling at the place of residence, work, and study of respondents. The main motive for participants in volunteer activities is the altruistic reason. $8.1 \%$ of volunteers have defined their sphere of activity as volunteerism in emergencies. $31.9 \%$ are potentially ready to help people in emergency situations. This variance in figures we could explain by the fact that many volunteers do not
\end{abstract}


have enough necessary skills. Besides, the participation in emergency situations liquidation, traffic accidents, fire extinguishing, etc., is associated with possible risk.

Keywords: emergency situation, population protection, civil society, volunteering, social activity.

\section{Introduction}

To date, the volunteer movement has firmly been established in society as one of the indispensable institutions. It is perceived behavioral patterns, symbolic system, value characteristics, and other attributes, associated in sociological discourse with social institutions, are indeed noticeable. Their recognition in its own right serves as a measure of legitimacy for the results of sociological reflection on volunteer practices. In this regard, the main effect of what we can call the "establishment of the volunteer movement," both in Russia and in the global community at large, is precisely this pre-reflexive obviousness of volunteering, its "social significance,” recorded before and outside of any formal procedures for determining successfulness (Zborovsky, 2017). This context makes volunteering a self-contained object of sociological, political, or even psychological research. In its turn, a form of this self-sufficiency could be the study of the volunteer work from the position of its actors, whose actions are seen in a broad and rather "pedagogical” perspective. It implies the interpretation of volunteering either as a factor in the formation of the subject, or as a kind of a projective test, allowing to see the personality of an individual, a valuable member of society, or a representative of the "modern youth."

The history of a systematic sociological study of volunteering could be traced back to several decades (Zborovsky, 2017). While proceeding with it in this article, among other issues, we will try to point out that the problems of volunteer work in an emergency situation (emergency) appear to be at the intersection of the most significant issues raised by volunteer research. In the future, they will require a unique approach to the analysis that differs from the trends of modern sociological representation of the volunteer movement (Lauber \& Ulandowski, 2019).

It is extremely challenging to estimate the degree of volunteers' readiness to participate in events related to emergency response, and their interest in such activities. Obviously, the established language of volunteer activities description suggests a focus on achieving, first of all, personal goals. Nevertheless, the systematization of options for volunteer work in this sphere, as well as the clarification of the place of involvement in relevant activities in the expectations system from the volunteer work, remains a step towards a holistic description of 
volunteering as an element of social relations in the modern society. Therefore, the purpose of this research is to identify the motives, types, and areas of volunteering in the system of emergencies liquidation in Russia, to study the potential for involvement of volunteers in emergency situations.

\section{Materials and methods}

The study implied a combination of theoretical and empirical methods. Among the first ones were: theoretical analysis of scientific literature, research, and generalization of the experience of using the potential of volunteering in emergencies in the academic discourse. The current research also used the materials from the most significant foreign studies of volunteering (Müller, Hameister, \& Lux, 2016; Olk, 2011; Vogel et al., 2016) and studied volunteer surveys conducted by the All-Russian Center for Public Opinion Research (VTsIOM) (Russian Public Opinion Research Center, 2017) and the Center for Civil Society and NonProfit Sector Studies of the National Research University - Higher School of Economics (HSE) (Mersijanova \& Korneeva, 2013; Mersijanova, 2018) over the past nine years.

To obtain the quantitative characteristics of the problem under consideration, 480 people were polled among volunteers of the Lipetsk region. The questionnaire contained nine questions. The purpose of the survey was to analyze basic forms of public activity of volunteers. The lack of data on the general population allowed us to focus on the calculations of V. I. Paniotto, who determined the optimal volume of 400 people with an assumption of a $5 \%$ error (Paniotto \& Maksimenko, 1983). The following criteria were fundamental for determining the sample population: sex, age (under 25 years; 26-45 years; 46 years and older), and education of respondents. $75.8 \%$ of respondents studied in universities and colleges: $46 \%$ of them graduated from universities, $29.8 \%$ received secondary professional education. $12.1 \%$ had higher education, $12.1 \%$ had secondary education. Distribution of respondents by age groups: under 25 years $-75.8 \%$, from 26 to 45 years - 18\%, over $46-6.2 \%$. The oldest volunteer was aged 62. The youngest one was 16 years old. Among the interrogated, there were $38.9 \%$ of men and $61.1 \%$ of women.

Subsequently, after the beginning of the coronavirus pandemics, an additional study was conducted, interviewing 400 people. Among the interviewed people, there were $38.5 \%$ males, $61.5 \%$ females. The survey was conducted with two questions. The purpose of the interrogation was to find out the readiness of volunteers to participate in the events of All-Russian action of mutual assistance during the coronavirus pandemic "We are together." The volume of samples and the method of primary material processing provide a standard measurement error. The 
maximum allowable error of sampling does not exceed $\pm 2.7 \%$ at the probability of its occurrence 0.95 (Paniotto \& Maksimenko, 1983). The processing and analysis of empirical data was carried out with the SPSS software and analysis system.

\section{Results}

According to the "Concept for Developing Volunteering (Voluntary Service) in the Russian Federation till 2025” (Order of the Government of the Russian Federation from 27.12.2018 N 2950-r “On approval of the concept for developing volunteering (voluntary service) in the Russian Federation till 2025”), volunteering is considered to be one of the priority areas of social and youth policy. It goes quite in accordance with the global trend, which suggests increased attention to volunteerism as a social force. The International Labor Organization recognizes volunteer work as "a key resource for addressing social and environmental issues around the world" and a resource for "improving the quality of life" (International Labour Organization, 2011, p. 1). Documents of such international organizations as the European Parliament and the Council of the European Union periodically mention the volunteer work as an important resource for society development (The Council of the European Union, 2010; The European Parliament, 2010). Here, the traditional set of rhetorical figures includes the reference to the volunteer experience as an effective mechanism for forming primary competencies, improving social wellbeing and welfare in the country and the region, developing the culture of local communities.

The sociological research conducted in Russia allows us to study this type of volunteering in the context of the volunteer movement in its whole, especially taking into account its quite specific structure in Russia.

According to the nationwide Russian survey conducted in 2011 by the Center for Research of Civil Society and Non-commercial Sector at the HSE, 25\% of the interrogated were engaged in the "voluntary and gratuitous activity" during the last year (Mersijanova \& Korneeva, 2013, p. 45). The 2017 survey, conducted by the same organization, revealed that $33 \%$ of respondents participated in "some way or another" in volunteer activities, and $15 \%$ of respondents chose the option "definitely had a chance to take part" while answering (Mersijanova, 2018, p. 19). According to the data obtained by VTsIOM (Russian Public Opinion Research Center, 2017), which interviewed more than 5 thousand volunteers, the most significant areas of their activities were distributed in the following manner: 78\% of volunteers participated in the organization and execution of events; $41 \%$ were involved in the field of sports; 30\% were involved in social protection and ecology. Characterizing the motivation of 
volunteers in the same study, 55\% of whom were in the age group from 18 to 24 years, the authors of the study grouped possible motives, singling out the motivation related to leisure and new experience and professional development and career, getting naturally equal shares: $48 \%$ and $47 \%$ respectively. The most popular specific motive was "a desire to spend time excitingly and live an active life" (48\%).

Distribution of volunteers by areas of volunteer activities (Table 1) demonstrates a shift towards social protection. Almost half of the respondents $(44.0 \%)$ chose a corresponding answer option, which is in line with the range of volunteer work offered by public associations and state organizations, and with the sustainable image of this work, in response to the need of the vulnerable groups of the population. The option of "volunteering in emergency situations" was chosen by $8.1 \%$ of respondents. Such a percentage of answers we should consider to be rather high, considering the occasional demand for this area of activity and level of training necessary for its implementation. Among those who chose this option, men prevail $(21.5 \%$ of them chose this option so far; among women the rate is only $0.7 \%$ ). Besides, the sum of choices of social protection, medicine, precisely emergency situations, search for people and psychological assistance demonstrates sufficient involvement of volunteers in activities that are in demand in the conditions of facing natural and anthropogenic disasters. 


\section{Table 1}

Distribution of the respondents' answers to the question "What is your area of volunteerism?" (any number of answers, \%)

\begin{tabular}{cc}
\hline Variant & Results \\
\hline 1. social protection & 44.0 \\
2. culture, leisure, arts & 32.0 \\
3. the improvement of the urban environment & 28.0 \\
4. education, enlightenment & 17.9 \\
5. patriotic education and military training & 12.1 \\
6. environmental protection, environmental volunteering & 10.0 \\
7. development of public activity & 10.0 \\
8. medicine & 7.9 \\
9. volunteering in emergency situations & 8.1 \\
10. search for individuals & 5.8 \\
11. corporate volunteering & 5.8 \\
12. psychological assistance & 4.0 \\
13. legal protection & 1.9 \\
14. sport and tourism activities & 1.9 \\
\hline
\end{tabular}

The leading target group of volunteers are persons with disabilities (Table 2), the elderly, and children, which can be considered appropriate for distributing activities described above. What is important here is the share of those who chose the option "with all those who need help/service” (49.0\% on the whole sample population), corresponding mainly to the participants of volunteer organizations of educational institutions involved in a wide range of low differentiated volunteer "actions" and forming the basis of the sample population. The same context determines the choice of "organizing and conducting events" as the most attractive form of volunteer work (47.9\%), combined with the low attractiveness of individual assistance. 


\section{Table 2}

Distribution of the respondents' answers to the question "What target group do you work with?" (any number of answers, \%)

\begin{tabular}{cc}
\hline Variant & Results \\
\hline 1. children with disabilities & 17.9 \\
2. orphans & 4.0 \\
3. with children from care homes and orphanages & 10.0 \\
4. with elderly people & 12.1 \\
5. children from dysfunctional families & 4.0 \\
6. sports and tourism activities & 6.0 \\
7. families in a difficult life situation & 4.0 \\
8. disabled people (adults) & 7.9 \\
9. military personnel, veterans of combat operations & 1.9 \\
10. women & 1.9 \\
11. peacekeeping, development of international relations & 0.4 \\
12. with all those who need help/service & 47.9 \\
\hline
\end{tabular}

The problem of clarifying volunteer motivation, as we mentioned above, remains extremely vital (Table 3). Considering the limited opportunities, which sociology has in this case, we are talking about identifying the preferred answers. They correlate not only with the motivation itself, of which a person is not always a confident interpreter, but also with the functioning of the language of description of volunteer activity, including in the official sphere. Under these conditions, the prevalence of altruistic motive (“desire to help people,” 32.1\%) is indicative, but characterizes instead the general attitude towards volunteering. It differs from most foreign studies, but is quite consistent with the above distribution of volunteer activities in the conducted research. It should also be noted that $12.8 \%$ of the respondents named their benefits (such as higher student scholarships, trips, etc.) as a significant motive. The least common motives are free time and the prestige of volunteerism. Interestingly, among men, the altruistic motive (31.4\%) is no longer dominant, giving way to the "desire to expand the social circle” (44.1\%), while among women the most attractive option was the "opportunity to get 
useful skills" (in the latter case, the significance of altruistic motive was comparable (32.8\% and $32.5 \%$, respectively).

\section{Table 3}

Distribution of the respondents' answers to the question "What are your personal reasons for volunteering?” (any number of answers, \%)

\begin{tabular}{|c|c|}
\hline Questions & Results \\
\hline 1. a drive to help other people & 32.1 \\
\hline 2. an opportunity to get useful skills & 27.9 \\
\hline 3. desire to expand the social circle & 26.0 \\
\hline 4. a higher scholarship & 4.0 \\
\hline 5. traveling & 8.1 \\
\hline 6. availability of free time & 7.9 \\
\hline 7. prestige of volunteering & 4.0 \\
\hline
\end{tabular}

The results of the answers to the question on the continuation of participation in volunteer movement are also of particular interest. The majority of respondents (66\%) could not give a definite answer, although only $1.9 \%$ were sure about their unwillingness to volunteer in the future. This distribution of answers, at least to some extent, again, can be explained by the concentration of volunteer movements within educational institutions. It prevents participants from confidently speaking about their participation in volunteer work after graduating from the affiliated institutions.

When choosing the most attractive potential sphere of volunteer activity, the largest number of the respondents (81.9\%) indicated the option "assistance in organization of leisure activities”, which implies the organization of leisure time for socially unprotected categories, but obviously allows to implement several personal motives to the utmost extent. The desire to participate in social projects to help children, disabled people, people in difficult life situations, and elderly people (77.9\%) is characteristic, directly corresponding primarily to altruistic motivation. In the context of the article's objectives, we would like to draw attention to the high percentage of election options related to emergency assistance (31.9\%), which is significantly higher than the rate of those who participated in such activities. While women practically show 
no interest in helping people in emergency situations (1.6\% of the interrogated), for men it is one of the most attractive types of activity (86.1\%).

The survey also revealed that the awareness of volunteers about organizations focused on assistance in emergency situations remains relatively low. Only more than half of the interrogated (57.9\%) know about public associations organized by firefighters. Awareness of volunteer rescuers and voluntary psychological movements is much lower (28.5\% and $16.9 \%)$.

According to the poll's data, the absence of spare time is naturally the most frequently mentioned reason for the impossibility to pay more attention to volunteer activities (question 9). For that, It is interesting to compare the obtained figures with the data gained in the additional survey $(n=400)$ conducted in April 2020 and aimed at finding out the readiness of volunteers for the All-Russian action of mutual assistance during the coronavirus pandemic "We are together." The data on volunteers' willingness to help and their preferred activities are shown in Table 2. The readiness to participate (question 1) was stated by $58 \%$ of respondents, but, in contrast to the situation with potential participation in emergency response, which was clarified in the first survey, those willing to participate were almost evenly distributed among gender groups, which should be explained by the peculiarities of a particular situation. The most preferred activities (question 2) were the delivery of products and medicines, informing the population, and assistance in solving domestic problems.

\section{Table 4}

The data from a sociological survey of volunteers in the Lipetsk region during the coronavirus pandemic (\%)

\section{Questions}

\section{Results}

1. Are you ready to help people in quarantine, including the lonely, during the coronavirus pandemic?

$$
\text { 1.1. ready to help }
$$

2. If you are ready to volunteer during a coronavirus pandemic, how do you prefer to do it? (any number of answers) 
2.4. ready to inform others about the ways of coronavirus transmission, methods of its prevention

2.5. ready to assist law enforcement agencies in establishing the chain of contacts of those infected with coronavirus infection

\section{Discussion}

The data obtained in the research course reflect the volunteer movement state in a particular region of the Russian province and cannot be extended to volunteerism in Russia as a whole. It should also be kept in mind that the proposed answers to the questionnaire deliberately excluded intentionally provocative statements, assuming a voluntary interest in volunteer activities.

It would be reasonable to compare the results with those of similar studies. To date, we have both the results of single surveys of different breadth conducted to determine the degree and nature of citizen engagement in volunteer activities, and the data obtained in the course of long-term monitoring studies. The topics touched by such surveys, apparently, can be conventionally divided into two segments of unequal size and value. The first one can be roughly denoted as a statistical one. It includes the whole volume of received factual information, which does not require interpretative actions from the respondents. The second segment involves addressing the volunteers’ personal opinions and has a conditionally personal and interpretive character. We can try to clarify the degree of the volunteers' satisfaction with their activities, their evaluation of the organization of the volunteer movement, etc., although the main problem of the segment remains the problem of motivation.

The majority of the authors who tried to generalize the data on the volunteers' motivation reproduce the same model of changes in respondents' attitudes. It is assumed that the altruistic motivation associated with giving aid and fulfilling a duty gradually gives way to personal motivation for communication and personal development (Lauber \& Ulandowski, 2019, p. 54; Olk, 2011, p. 710). An extensive German study conducted in 2014 identified the following hierarchies of motives characteristic of volunteer movement participants (from the most common motive to the least common): to have fun (Spaß haben); to meet other people; to help shape society (Gesellschaft mitgestalten); to communicate with people of different generations; to acquire qualifications; to gain reputation and influence; to improve professional skills; to earn money (Müller et al., 2016, p. 427). At the same time, the first, admittedly "hedonistic" motive, given the totality of those who agree entirely and those who agree more 
strongly, was named by $93.9 \%$ of the interrogated volunteers. Such a structure of motivation quite corresponds to the design of the volunteer activity itself. According to the same research, sport, and physical activity_-Sport und Bewegung — was the most demanded field in Germany (16.3\% of the interrogated) (Vogel et al., 2016).

Similar results are demonstrated by domestic surveys. Characterizing the motivation of volunteers, 55\% of whom were in the age group from 18 to 24 years, the authors of the study (Russian Public Opinion Research Center, 2017) grouped possible motives, singling out the motivation related to leisure and new experience and professional development and career, getting naturally equal shares: $48 \%$ and $47 \%$ respectively. The most popular specific motive was "a desire to spend time excitingly and live an active life" (48\%).

The survey, which became the main subject of this article, allows us to draw different conclusions, indicating a relatively even distribution of the motifs with the altruistic priority. This allows us to talk about the potential readiness of volunteers to participate in measures to overcome the consequences of emergency situations, which is confirmed by direct answers to the relevant questions.

\section{Conclusion}

The sociological study made it possible to conclude that, for most volunteers, the essence of volunteerism is expressed in the activities that directly benefit those in need, which is accompanied by the acquisition of new experiences and active participation in public life. The main motive, named by the volunteers, is the altruistic one, which is more often chosen than the motive for personal development. Most volunteers work in the field of social protection, which reflects the overall structure of the volunteer movement in the country. Only $8.1 \%$ of volunteers defined their sphere of activity as "volunteering in emergency situations," but in general, almost $1 / 3$ of the respondents are ready to participate in helping people in emergencies. Among the interrogated men this index reaches $86.1 \%$.

Likewise, the sociological survey data demonstrate the potential for involving volunteers in the work of protecting the population and territories from emergencies, as well as the need to further expand volunteer training programs in emergency situations. In general, the survey showed a high level of interest in volunteers in participating in emergency response activities. It suggests that in modern circumstances, conditions have been created for the formation of a pool of trained volunteers capable of providing help in the event of emergency situations. 


\section{References}

International Labour Organization (2011). Manual on the measurement of volunteer work. Retrieved from https://www.ifrc.org/docs/IDRL/Volunteers/ILO\%20Manual\%20on\%20Measurement \%20of\%20the\%20Volunteer\%20Work.pdf

Kulikovsky, S. S., Malysheva, I. S., \& Malyshev, I. Y. (2017). On the problem of interaction of the Ministry of Emergency Situations of Russia with civil society institutions. Fire Safety. Problems and Perspectives, 1(8), 14-17. Retrieved from https://cyberleninka.ru/article/n/k-voprosu-o-vzaimodeystvii-mchs-rossii-s-institutamigrazhdanskogo-obschestva/viewer

Lauber, K., \& Ulandowski, K. (2019). Motive engagierter Studierender - Engagement in einer Phase beruflicher und persönlicher Identitätsentwicklung. In C. Möller, \& H. Rundnagel (Eds.), Freiwilliges Engagement von Studierenden (pp. 51-72). doi:10.1007/978-3-65824771-3_4

Mersijanova, I. V. (Ed.). (2018). Assessment of the economic and social effectiveness of volunteer activities: methodological approaches and implementation problems. Retrieved from https://grans.hse.ru/data/2018/03/07/1165678462/\%D0\%94\%D0\%BE\%D0\%B1\%D1 \%80\%D0\%BE\%D0\%B2\%D0\%BE\%D0\%BB\%D1\%8C\%D1\%87\%D0\%B5\%D1\%81 \%D1\%82\%D0\%B2\%D0\%BE_\%D0\%B4\%D0\%BB\%D1\%8F_\%D1\%81\%D0\%B0\%D 0\%B9\%D1\%82\%D0\%B0.pdf

Mersijanova, I. V., \& Korneeva, I. E. (2013). Charity and participation of Russians in the civil society practices: the regional dimension. Retrieved from https://publications.hse.ru/mirror/pubs/share/folder/06pidyi2ww/direct/117829593.pdf Müller, D., Hameister, N., \& Lux, K. (2016). Anstoß und Motive für das freiwillige Engagement. In J. Simonson, C. Vogel, \& C. Tesch-Römer (Eds.), Freiwilliges Engagement in Deutschland. Empirische Studien zum bürgerschaftlichen Engagement (pp. 413-435). doi:10.1007/978-3-658-12644-5_16

Olk, T. (2011). Qualitative Forschung. In T. Olk, \& B. Hartnuß (Eds.), Handbuch Bürgerschaftliches Engagement (pp. 705-718). Weinheim: Beltz Juventa.

Paniotto, V. I., \& Maksimenko, V. S. (1983). Quantitative methods of sociological research. Kiev: Naukova dumka. 
Russian Public Opinion Research Center. (2017). Demand for non-material measures to encourage volunteerism. Retrieved from https://volonter.ru/wpcontent/uploads/2017/12/Mery-nematerialnogo-pooshhreniya-volonterstva.pdf

The Council of the European Union. (2010). Council decision of 27 November 2009 of the European year of voluntary activities promoting active citizenship (2011) (2010/37/EC). Official Journal of the European Union, 53, 43-49. Retrieved from https://ec.europa.eu/citizenship/pdf/20091127_council_decision_en.pdf

The European Parliament. (2010). European Parliament resolution of 22 April 2008 on the role of volunteering in contributing to economic and social cohesion (2007/2149(INI)). Official Journal of the European Union, 259, 9-13. Retrieved from https://op.europa.eu/lt/publication-detail/-/publication/e3f1c72a-29cf-4343-9d4abcb7566b67f8/language-en

Vogel, C., Hagen, C., Simonson, J., \& Tesch-Römer, C. (2016). Freiwilliges Engagement und öffentliche gemeinschaftliche Aktivität. In J. Simonson, C. Vogel, \& C. Tesch-Römer (Eds.), Freiwilliges Engagement in Deutschland. Empirische Studien zum bürgerschaftlichen Engagement (pp. 91-152). doi:10.1007/978-3-658-12644-5_4

Zborovsky, G. E. (2017). Relevance of volunteering in the structure of sociological knowledge. PNRPU Sociology and Economics Bulletin, 3, 8-23. doi:10.15593/2224-9354/2017.3.1 